CIESIN Reproduced, with permission, from: Gomez-Pompa, A., C. Vasquez-Yanes, and S. Guevara. 1972. The tropical rain forest: A non-renewable resource. Science 117 (4051): 762-65.

\title{
The Tropical Rain Forest: A Nonrenewable Resource
}

\section{A. Gomez-Pompa, C. Vazquez-Yanes, S. Guevara}

There is a popular opinion that the tropical rain forests because of their exuberant growth, their great number of species, and their wide distribution will never disappear from the face of the earth.

On the other hand, it has often been stated that the tropical rain forests (tall evergreen forests in tropical warm and humid regions) around the world must be protected and conserved for the future generations $(\underline{1})$. It has also been stated that it is most important that knowledge about the structure, diversity, and function of these ecosystems has priority in future biological research (2). Unfortunately, either these voices have not been heard or their arguments have not been convincing enough to promote action in this direction.

It is the purpose of this article to provide a new argument that we think is of utmost importance: the incapacity of the rain forest throughout most of its extent to regenerate under present land-use practices.

Even though the scientific evidence to prove this assertion is incomplete, we think that it is important enough to state and that if we wait for a generation to provide abundant evidence, there probably will not be rain forests left to prove it.

During the last few million years of their evolution, the rain forests of the world have produced their own regeneration system through the process of secondary forest succession. This regeneration system evolved in the many clearings that occurred naturally as a result of river floods, storms, trees that die of age, and the like. The genetic pool available for recolonization was great, and a number of populations and species with characteristics that were advantageous in the rapid colonization of such breaks in the continuity of the primary rain forest were selected. These plants were fast-growing heliophytes, with seeds that have dormancy and long viability, and efficient dispersal mechanisms $(\underline{3}, \underline{4})$. These sets of species played a fundamental role in the complex process of regeneration of the rain forest, and it is astonishing that very little is known about their biology, their behavior in the succession, and their evolution, even though they are the key to understanding the process of secondary succession, which is one of the most important ecological phenomena. The few works on the subject point out that there are certain repetitive patterns that can be predicted and that the species involved are fundamentally different from the primary species (므그). 
It is still uncertain how most of the primary species of the rain forest reproduce themselves and how the forest is regenerated, but from the evidence available it seems that there is a very complex system working at different times and in different directions, depending on the local situation and the plants involved (י).

One of the most important aspects of natural regeneration is that on the floor of the primary rain forest there are always seedlings of young plants of many of the primary tree species. Under the effects of disturbance these seedlings will continue growing at an increased rate ()ㅡ, , and, at the same time, the secondary species start growth from dormant seeds in the soil. After several years the primary species will have grown taller than the secondary ones, and the major step in the regeneration has been accomplished.

There are taking place at the same time other processes, such as the colonization of trees and shrubs by epiphytic plants, about which even less is known, as well as the growth and establishment of climbing plants that has occurred probably since the early stages and of which many species will grow to the upper canopy of the rain forest. In all these cases the key plants are the seedlings of tall primary trees that will take over the upper canopy of the old successional series.

The regeneration of these primary species by the seedlings or young plants inside the forest is not the only possible way. Another important means of regeneration comes from seeds in the soil (9). In tropical rain forests this type of regeneration seems to be very effective mainly for species that happen to be in fruit during the disturbance of the area, because apparently there is a very short dormancy of the seeds of most of the primary species and the entire life of seeds of tropical tree species is in many cases very short ( 8 , $\underline{10}-\underline{12})$.

It seems appropriate to mention that we realize, of course, that the many, and quite different, primary tree species in the rain forests of the world may behave very differently in their germination responses and life-span. The available evidence indicates, nevertheless, that many primary tree species have large seeds $(\underline{8}, \underline{13})$ with either short dormancy or none at all ( $\underline{10})$. The biological implications of this phenomenon are barely known (14), but it seems that the general trend is toward rapid germination, which is usually advantageous to the survival of the species. If one considers the predators of all types (fungi, bacteria, animals of various types) that are present in tropical warm and humid conditions, it seems reasonable to attribute survival power to the species, the seeds of which can germinate quickly and the seedlings of which can remain alive for a long time in a slow-growing condition (8). The scarcity of seeds of primary trees stored in soils from rain forests has been demonstrated in one area in Mexico ( $\underline{9}$ ), but many more studies in this direction are needed, even though this fact has been noted earlier $(\underline{8}, \underline{11})$.

Another possibility for the establishment of primary tree species in the early stages of regeneration is by long-distance dispersal by birds and by other animals such as monkeys, rodents, and others. 
Very little is known about fruit and seed dispersal of tropical forest species $(\underline{12}, \underline{15})$, but it seems that long-distance dispersal has played, and is playing, an important role in areas where human disturbance has not reached a critical level. The phenomenon of longdistance dispersal of tropical trees has almost never attracted the attention of researchers, but it may be extremely important in understanding the evolution of local populations and the adaptation to local ecological conditions (16), even though, from the point of view of regeneration, it may have little importance. Still another means of reestablishment of primary species in the early stages of succession is vegetative reproduction by means of rhizomes, bulbs, and roots that may remain alive after the destruction of the original forest and become active soon after the disruption.

\section{Man and the Tropical Rain Forest}

All that has been considered to this point concerns natural regeneration caused by natural catastrophes. The regenerative system of the rain forest seems to be very well adapted to the activities of primitive man. The use of small pieces of land for agriculture and their abandonment after the decrease of crop production (shifting agriculture) is similar to the occasional destruction of the forest by natural causes $(\underline{17}, \underline{18})$. This type of activity can still be seen in many tropical areas where a mosaic pattern can be found, with large pieces of primary rain forest and patches of disturbed forest of different ages from the time of their abandonment. Several studies of these successional series are available ( $\underline{9}$, $\underline{17}, \underline{19}-21$ ), and in most cases they tend to agree that shifting agriculture has been a natural way to use the regenerative properties of the rain forest for the benefit of man. How this operates is not well known, but we can extrapolate our knowledge of the natural regeneration of the rain forests and compare it with the data available. After the abandonment of the land by the primitive farmer, regeneration starts with the available seeds and other propagules in the soil. At present the seeds known to remain viable in the soil are mainly those of secondary species ( $\underline{9})$. After cultivation of an area, the possibility of any seedlings or young plants of the trees of the closest primary forest persisting is almost nil, and, because of the time involved in crop production, most of the future propagules of primary trees have to come in by natural dispersal (such as animals, water, gravity, or air).

There are several problems involved in connection with the speed of regeneration under these circumstances, but, in general, one can say that under the shifting cultivation system, the genetic pool of primary trees is retained, and from this pool comes the raw material for the successional processes. Of course, this is true in all cases where demographic pressure has not forced an intensive shifting agriculture with short periods of recovery, as in some tropical regions $(\underline{20}, \underline{22})$.

We think that it is evident that the importance of retaining pieces of the original forest as the only way to (21) construct future forests cannot be over stressed. Whether the system of shifting agriculture is responsible for the extinction or simplification of some of the present tropical ecosystems is not completely certain, but it does seem clear that it prevents a mass extinction of species. 
We cannot overstress the importance of the space factor in these considerations, because it makes an enormous difference if we use or destroy thousands of square kilometers or if we destroy one or two.

\section{The Tropical Rain Forest in the Green Revolution Era}

In recent times the trend in many tropical areas has been to look for ways to make permanent use of the land, in contrast with the old way of shifting cultivation. Permanent use can be accomplished with the help of the new technology and chemicals that have proved to be successful in many tropical areas. These methods have opened greater possibilities for making available large extents of land for agricultural crops; the new trends can be seen in almost any tropical area today (Fig. I). We shall not consider the problems of such methods and their possible consequences (21, 23, 24). Instead, we analyze this end in relation to the natural regeneration process.

Under an intensive and extensive use of the land, sources of seeds of primary tree species for regeneration becomes less and less available because of the dispersal characteristics of those species and because of the scarcity of individuals of most of the tree species. (25). The only species available that are preadapted for continuous disturbance are secondary species or primary species with some of the characteristics of the secondary ones (26). This group of species has characteristics that enable them to thrive in such conditions; they produce large numbers of seeds, which have means of long-distance dispersal and dormancy; these seeds accumulate and stay alive in the soil (that is, they have a long life-span). The process often called "savannization" and "desertization" (27, 28) of the tropical humid regions can very well be explained by these characteristics.

Also, plants preadapted for disturbance such as ones from drier environments with builtin adaptations to remain alive in a dormant condition for long periods of time may invade these areas and allow them to regenerate a forest vegetation.

An ecosystem consisting of secondary species mixed with species from drier environments will become established. Since these species are generally lower in stature at maturity, the vegetation will also be lower in stature than the one the climate can allow. According to this view, some of the vegetation types that have these characteristics---for example, some low semi-evergreen selvas, savanna woodlands, and savannas in Mexico (29) , as well as some in Asia (28), Africa (30), and South America (27, 31)---may be the product of an extensive and intensive shifting agriculture of old cultures. Some of the old arguments on the effects of fire for the explanation of many of the anthropogenous savannas and savanna woodlands can be explained better with the idea that we propose of the mass extinction of many tall tree species.

Thus there may be a possibility of bringing back some of these areas to a tall forest condition by introduction of the proper trees. There is. however, a great lack of information about population differentiation in tropical tree species, and research in this field is urgently needed for making basic recommendations in tropical rain forest management $(\underline{16}, \underline{18})$. 
An example of this problem is the failure of a project of one of us (A. G.-P.) for study of population differentiation in a tropical rain forest species, Terminalia amazonia. Seed populations were collected from Central America and Mexico, and, after germination, the young plants were transplanted to an introduction station at the Mexican site of the collections. The study had to be discontinued, for all the seedlings from the populations from Central America were exterminated by predators, especially ants, and comparisons could not be made. It is interesting that in this case probably there has been evolution in connection with the chemical protection against local predators which is not reflected in the morphology because morphological differences can hardly be distinguished. This study needs to be repeated with other species, but it shows that there is a potential problem in induced regeneration by the introduction of seeds from distant populations. This idea has also been developed from the problem of biological control of tropical pests $(\underline{24})$.

\section{Other Implications}

All the facts and ideas mentioned lead us to the conclusion that, with the present rate of destruction of the tropical rain forests throughout the world, there is great danger of mass-extinction of thousands of species. This is due to the simple fact that primary tree species from the tropical rain forests are incapable of recolonizing large areas opened to intensive and extensive agriculture. There has been a long controversy among persons responsible for the intensive use of land in the tropics, and it seems that the most important argument has been that countries like those of Europe, the United States, and some temperate Asiatic ones (Japan) have used the land intensively and extensively and there is not much evidence of mass disappearance of species. In view of the successional processes already discussed and with respect to the understanding of some biological properties of the species of northern temperate and cold areas, the explanation seems evident. In temperate areas the primary tree species are in many cases represented by a great number of individuals, and the distribution of many of the temperate species is large, and, in addition, many of them possess seeds adapted to long periods of inactivity, Thereby conserving their vitality (dormancy and long life-span) (2) for periods of time while buried in the soil. Even though there are no reliable records of the life-span of seeds of trees buried in the soil of temperate regions, the available data known to us (프) suggest strongly the possibility that seeds stored in soils long retain their potential for growth. All these aspects yield a very different general behavior of the land cleared for agriculture and its possible future regeneration. It is also important to note that an isolated tree from a primary temperate forest has greater probability of survival than an isolated tree from a tropical rain forest (18); this is due to the complex and delicate net of relationships of each individual with the environment. This means that a gene pool of primary trees can be maintained along roads, near houses, and the like, for temperate areas but not for the tropical rain forest. If we add to these ideas the great difference in number of national parks, arboreta. botanic gardens, and storage facilities in many temperate areas in contrast with the virtual absence of such resources in the tropics, the problem grows to an even larger and more critical dimension. 
All that we have said is applicable to tropical evergreen rain forests in the warm and humid areas of the world. In drier tropical areas with a definite long dry season the problem is very different, and the plants behave in connection with the problems of regeneration under intensive exploitation, in a manner more similar to those of temperate areas. The reason for this is that these plants are in some ways preadapted to great disturbances since they possess better characteristics for survival during periods of adverse conditions (drought, fire).

\section{Conclusions}

All the evidence available supports the idea that, under present intensive use of the land in tropical rain forest regions, the ecosystems are in danger of a mass extinction of most of their species. This has already happened in several areas of the tropical world, and in the near future it may be of even greater intensity. The consequences are nonpredictable, but the sole fact that thousands of species will disappear before any aspect of their biology has been investigated is frightening. This would mean the loss of millions and millions of years of evolution, not only of plant and animal species, but also of the most complex biotic communities in the world.

We urgently suggest that, internationally, massive action be taken to preserve this gigantic pool of germplasm by the establishment of biological gene pool reserves from the different tropical rain forest environments of the world.

The authors are in the department of botany at the Institute of Biology, National University of Mexico, Mexico 20, D.F.

\section{References and Notes}

1. C.G.G.J. van Steenis, Micronesica 2, 65 (1965); E.J.H. Corner, New Phyto. 45, 192 (1946).

2 P.W. Richards, Atas Simp. Biota Amazonica 7, 49 (1967).

3 A.Gomez-Pompa. Biotropica 3, 125 (1971).

4 E. Vazquez-Yanes and A. Gomez-Pompa, in Simp. Lathnoam, Fisiol, Vegetal, Qua, Lima, Peru 20 to 26 Sept. (1971), pp. 79-80; C.G. G.J. van Steenis, in Study of Tropical Vegetation. Proc. Kandy Symp., Dandy, Ceylon, 19 to 21 March 1956 (1958), pp.212218.

5 G. Budowski, Turrialba 15, 40 (1965) 
6 C.F. Symington, Malayan Forest. 2, 107 (1933); A. Gomez-Pompa, J. Vasquez-Soto, J. Sarukhan. Publ. Especial Inst.. Nacl. Invest. Forest. (Mexico) 3, 20 (1964).

7 J. Sarukhan, Publ. Especial. Inst. Nacl. Invest. Forest. (Mexico) 3, 107 (1964).

8 P.W. Richards, The Tropical Rain Forest (Cambridge Univ. Press, London. 1952).

9. S. Guevara and A. Gomez-Ponpa, J Aronld Arboretum Harvard Univ. 53, 312 (1972).

10 W. Croker, Botan, Rev. 4, 235 (1938); R.C. Barnard, Malayan Forest Res. Inst.. Res. Pamphlet, No. 14 (1954); T.B. McClelland, Proc. Fla. State Hort. Soc. 57161 (1944); J, Marrero, Caribbean Forest. 4, 99 (1942).

11 J.P.Schultz, Ecological Studies on Rain Forest in Northern Surinam (NoordHollansche Uitgevers Maatschappij, Amsterdam, 1960), p. 226.

12 L. van der Pijl, Proc. Kon. Ned. Akad. Wetensch. 69, 597 (1966); Principles of Dispersal in Higher Plants (Springer-Verlag, Berlin, 1969), p. 87.

13 , Biol. J. Linnean Soc. 1, 85 (1969).

14 D.H. Janzen, Evolution 23, 1 (1969).

15 N. Smythe, Amer; Nature. 104, 23 (1970).

16 A Gomez-Pompa, J. Arnold Arboreium Harvard Univ. 48, 106 (1967).

$17 \_$Biol. Divulgacion Soc. Mex. Hist. Nat. 6, 5 (1971).

18 G.N Baur, The Ecological Basis of Rainforest Management (Blight Government Printer, New South Wales, 1968).

19 H.C. Conklin, FAO Forest, Develop. Pap. 121 (1957); E. Herandez X., Chapingo 2, 1 (1962); M.A. Martinez, Bol, Especial Inst. Nacl. Invest. Forest. (Mexico) 7, 1 (1970); P.H. Nye and D.J Greenland, The Soil under Shifting Cultivation (Commonwealth Bureau of Soils, Harpenden, 1960); M. Sousa, Publ. Especial Inst. Nacl. Invest. Forest. (Mexico) 3, 91 (1964).

20 J.M. blaut, in Symposium on the Impact of Man on Humid Tropics Vegetation, Goroka (1960), pp. 185-198.

21 J. Kadlec, Coordinatior, Man and the Living Environment, Workshop on Global Ecological Problems (Univ. of Wisconsin Press, Madison, 1972), p. 176. 
22 W.R. Geddes, in Symposium on the Impact of Man on Humid Tropics Vegetation, Goroka (1960), pp. 42-56; A. Dilmy, ibid., pp. 119-122; H. Sioli and H. Klinge, in Int. Symp. Stalzenau, The Hague (1961), pp. 357-363.

23 F. Tamesis, in Proc. Forest. Cong. 5th Seattle (1960), pp. 2025-2032; H.C. Conklin, Trans. N.Y. Acad, Sci. 17, 133 (1954).

24 D.H. Janzen, Bull. Ecol. Soc. Amer. 54, 4 (1970).

25 G.A. Black, Th. Dobzhansky, C. Pavan, Botan. Gaz. 111, 413 (1950); M.E.D. Poore, J. Ecol. (Jubilee Symposium) 52, 213 (1964); F.R. Fosberg, Trop. Ecol. 11, 162 (1970); V.M.toledo and M. Sousa, Bol. Soc. Botan. Mex., in press; other papers on the same subject appear in Speciation in Tropical environments, R.H. Lowe-McConnell, Ed. (Academic Press, New York, 1969).

26. A. Gomez-Pompa, Estudios Botanicos en la Region de Misantla, Veracruz (Ediciones del Instutio Mexicano de Recursos Naturales Renovables, A.C., Mexico, D.F., 1966), p. 104.

27 G. Budowski, Turrialba 6, 22 (1956); F.W. Went and N. Stark, BioSci. 18, 1035 (1968).

28 M. Schmid, in "Study of Tropical vegitation," Proc. Kandy Symp., Kandy Ceylon, 19 to 21 March 1956 (1958), pp. 183-192.

29 F. Miranda and E. Hernandez X., Bol. Soc. Botan. Mex. 28, 29 (1963); A. GomezPompa, ibid. 29, 76 (1964).

30 R. Sillans, thesis, Faculte des Sciences de l'Universite de Montpellier (1958), p. 176.

31 M.G. Ferri, Simposio o Cerrado (Edit. Univ. de Sao Paulo, Sao Paulo, 1963).

32 L.V. Barton, Seed Preservation and Longevity (Hill, London, 1961); Anon., Misc. Publ. U.S. Dept. Agri. 654, 290, 361 (1948).

33 N.W. Olmstead and J.D. Curtis, Ecology 28, 49 (1946); H.J. Oosting and M.E. Humphreys, Bull, Torrey Bot. Club 67, 253 (1940).

34 Flora of Veracruz, contribution number 12. A joint project of the Institute of Biology of the National University of Mexico and the Arnold Arboretum and Gray Herbarium of Harvard University, to prepare an ecological floristic study of the state of Veracruz, Mexico. Information about this project was published in Anal. Inst. Biol. Univ. Nacl. Mex. Ser. Bot. 41, 1-2. Partially supported by NSF grant GB-20267X. 